\title{
Incidence and severity of cassava mosaic disease in farmer's fields in Ghana
}

\author{
S. K. TORKPO*, Y. GAFNI, E. Y. DANQUAH \& S. K. OFFEI \\ (S. K. T.: Forest and Horticultural Crops Research Centre-Kade, School of Agriculture, College \\ of Basic and Applied Sciences, University of Ghana, Legon; Y. G.: Agricultural Research Or- \\ ganization, Volcani Centre, Israel; E. Y. D \& S. K. O.: Department of Crop Science, School of \\ Agriculture, College of Basic and Applied Sciences, University of Ghana, Legon \& West African \\ Centre for Crop Improvement, University of Ghana, Legon) \\ *Corresponding author's email:sktorkpo@ug.edu.gh/stephentorkpo@gmail.com
}

\begin{abstract}
A survey of cassava mosaic disease (CMD) was carried out in Ghana from 2007-2008 to assess CMD incidence, infection type, severity and adult whitefly population. A total of 136 famers' fields across major cassava producing areas in the Brong Ahafo, Western, Northern, Ashanti and Volta regions were assessed. CMD was prevalent in most of the 136 fields surveyed. Frequently encountered local landraces were susceptible to the disease. CMD incidence reached $100 \%$ in farmers' fields. Mean disease incidence ranged from $46 \%$ in the Ashanti region to $90 \%$ in the Western region of the country. CMD incidence averaged $66.0 \%$, with cutting-borne infection and Whitefly-borne infections being $54.0 \%$ and $12.0 \%$, respectively. CMD shoot symptom severity ranged from 2.0 to 3.7 in the farmers' fields, with a mean of 2.9. Mean adult whitefly population was 0.47 . The high prevalence of CMD requires a concerted effort in the management of CMD in the country.
\end{abstract}

Original scientific paper. Received 24 Jul 17; revised 04 Oct 17.

\section{Introduction}

Cassava is an important staple food for millions of people living in the tropical world (Bokanga \& Otoo, 1994; Legg, 1999) and is one of the most efficient crops for carbohydrate production. Cassava is a hardy crop, making it an ideal food security crop thus cultivated extensively in Ghana with yield of approximately 16 million metric tons (MOFA, 2016). Cassava is the most important staple in the country, with per capita daily intake of 642 calories, far exceeding maize and rice with 434 and 217 calories, respectively (FAO, 2006).

Cultivation of cassava is hindered by several factors, among which is cassava mosaic disease (CMD). The disease causes between $20-95$ per cent yield losses, with effects being more severe when plants are infected in the early stage of growth than when infected later (Otim-Nape et al., 1994; Thresh et al., 1994). Annual yield loss in Africa caused by CMD was estimated between US\$1.9 - 2.7 billion (Legg $\&$ Fauquet, 2004). CMD had been regarded as the most important disease of cassava in Africa (Sseruwagi et al., 2004). The disease is caused by cassava mosaic begomoviruses (CMBs), transmitted by the whitefly, Bemisia tabaci and perpetuated through cuttings, which is the usual method of propagating the crop (Otim-Nape et al., 1994). 
In Ghana, chlorosis and distortion of leaves and stunting of plants caused by CMD infections makes the disease very important (Lamptey et al., 1998). Although, fewer farms were covered in their 1997 survey, Cudjoe et al., (2005) reported occurrence of high, incidence of CMD in the country. Similarly, Torkpo \& Offei (2007) reported high incidence of the disease in farmers' fields in the Central and Eastern regions of Ghana. There was therefore the need for an extensive survey to assess the current status of CMD in other cassava producing regions of Ghana. The objectives of the present study were, therefore, to determine the current status of cassava mosaic disease incidence, infection type (cutting or whitefly-borne) and symptom severity, assess adult whitefly population on cassava fields and assess genetic variability within cassava germplasm in Ghana; and make recommendations for management of the disease

\section{Materials and methods}

The survey was conducted in 33 districts across five major cassava producing regions (Brong Ahafo, Western, Ashanti, Volta and Northern Regions) of Ghana, from November, 2007 January, 2008. Details of cassava production and the major crops grown in each district were obtained from the Ministry of Food and Agriculture (MoFA, 2007). Names of cultivars and age of plantings were provided by farmers and on few occasions by extension agents. Sampling interval between fields was $10-30 \mathrm{~km}$ along accessible roads. Thirty cassava plants (3 - 6 months) were randomly sampled along two horizontals and a diagonal across each field. CMD incidence, severity, and adult whitefly population were assessed only on the predominant cultivar while other cultivars, intercrops, field size (ha) and the number of visible cassava fields nearby were recorded. Coordinates of farms were taken with the Global Positioning System device, Garmin Geko 301 and the geographical distribution of CMD incidence and severity in Ghana plotted using the ArcView software (Environmental Systems Research Institute, Inc., Redlands, CA).

Cassava mosaic disease incidence was assessed by calculating the percentage of plants with symptoms. CMD infection was referred to as cutting-borne when lower leaves were diseased or as whitefly-borne when lower leaves were symptomless. CMD shoot symptom severity was assessed on a 1-5 scale of increasing severity (Hahn et al., 1980), where 1 and 5 , represented symptomless and very severe mosaic, respectively. Adult whitefly population was assessed by counting adult whiteflies on the abaxial side of the topmost five expanded leaves of the tallest shoot.

Means were calculated for CMD incidence, severity (score 2-5) and adult whitefly population. Data on CMD incidence was transformed using the arcsine while whitefly population data was transformed using the square root transformation. Standard error of difference values were calculated for means. Means of CMD incidence and adult whitefly population in tables are back-transformed figures.

\section{Results and discussion}

Farms covered during the study were typically subsistence, rarely exceeding one hectare. Most of the fields surveyed were planted with hard wood cuttings of local cassava landraces. Cassava fields surveyed in the study were assessed only once hence, no account was taken of seasonal changes that can influence disease incidence. Incidences of cassava mosaic disease were based on the expression of typical CMD symptoms on leaves. In all, seventy-two local genotypes and an improved genotype were recorded, out of which 45 predominated 
in one or more fields. Seven of these genotypes were assessed in more than four fields. Afisiafi, an improved cultivar did not predominate in any field. Some genotypes were grown only in one region. For instance, Biambash predominated in the Northern region but was not observed outside the region. Similarly, Dabor which predominated in 15 fields $(11.0 \%$ of the
136 fields) was not recorded outside the Ashanti and Brong-Ahafo regions. Koten (Pole) was the most widely recorded genotype, and was cultivated in nine districts. Bankye tuntum, Ankrah, Biambash, Ampenkyen and Wosre wonma were the other genotypes that predominated in more than four fields (Table 1).

TABLE 1

CMD incidence, severity and adult whitefly populations on cassava

genotypes assessed in three or more fields

\begin{tabular}{|c|c|c|c|c|c|c|}
\hline \multirow[b]{2}{*}{ Name of genotype * } & \multirow{2}{*}{$\begin{array}{l}\text { Number of times } \\
\text { recorded } * *\end{array}$} & \multicolumn{3}{|c|}{ CMD infection (\%) ${ }^{a}$} & \multirow{2}{*}{$\begin{array}{l}\text { Severity } a, b \\
\quad(1-5)\end{array}$} & \multirow[b]{2}{*}{ Adult Whitefly counts ${ }^{a}$} \\
\hline & & Total incidence & $\begin{array}{c}\text { Cutting-borne } \\
\text { infection }\end{array}$ & $\begin{array}{c}\text { Whitefly-borne } \\
\text { infection }\end{array}$ & & \\
\hline Dabor (8) & $18(15)$ & $20(3.06)$ & $5(3.87)$ & $15(3.20)$ & $2.8(0.14)$ & $0.4(0.04)$ \\
\hline Pole/Koten (9) & 19(14) & $95(4.73)$ & $84(7.87)$ & $10(6.86)$ & $3.2(0.15)$ & $0.96(0.10)$ \\
\hline Akosua tumtum (5) & $23(11)$ & $98(3.71)$ & $83(6.14)$ & $15(5.78)$ & $2.9(0.11)$ & $0.46(0.07)$ \\
\hline Ankrah (3) & $14(9)$ & $62(5.68)$ & $26(7.05)$ & $36(4.28)$ & $2.6(0.12)$ & $0.61(0.09)$ \\
\hline Wosre wonma (4) & $12(7)$ & $62(19.14)$ & $49(16.53)$ & $13(5.58)$ & $2.7(0.18)$ & $0.50(0.08)$ \\
\hline Biambash (2) & $6(6)$ & $83(12.74)$ & $70(17.50)$ & $13(8.26)$ & $2.8(0.26)$ & $0.19(0.05)$ \\
\hline Ampenkyen (3) & $11(5)$ & $99(4.24)$ & $89(11.21)$ & $10(10.40)$ & $2.8(0.18)$ & $0.28(0.04)$ \\
\hline Bankye korko (4) & $11(4)$ & $40(23.50)$ & $25(31.82)$ & $15(10.85)$ & $2.5(0.39)$ & $0.25(0.04)$ \\
\hline Esi Abeyem (4) & $10(4)$ & $86(14.50)$ & $78(9.45)$ & $8(3.38)$ & $3.2(0.20)$ & $0.68(0.10)$ \\
\hline Bosome nsia (3) & $7(4)$ & 100 & 100 & 0 & $3.4(0.13)$ & $0.45(0.02)$ \\
\hline Bankye Fufuo (3) & $9(3)$ & $40(33.91)$ & $33(42.42)$ & $7(8.92)$ & $2.7(0.50)$ & $0.44(0.09)$ \\
\hline Abrodwe (3) & $5(3)$ & 100 & $83(16.03)$ & $17(16.03)$ & $3.2(0.4)$ & $0.55(0.07)$ \\
\hline Bankye Ohemaa (1) & $3(3)$ & $92(10.96)$ & $85(3.38)$ & $7(8.69)$ & $3(0.37)$ & $0.26(0.04)$ \\
\hline
\end{tabular}

* Figures in parentheses are number of districts where genotype predominated

** Figures in parentheses are number of times the genotype was assessed

${ }^{a}$ Figures in parentheses are standard error of difference values

${ }^{\mathrm{b}}$ Cassava mosaic disease symptom severity scale: $1=$ symptomless and $5=$ very severe symptoms

There was substantial genetic variability within cassava germplasm cultivated throughout the regions surveyed and concurs with reports in other parts of Africa (Otim-Nape et al., 1998; Otim-Nape et al., 2001; Ntawuruhunga et al., 2007), where high genetic variability in cassava germplasm have been reported. The diversity among the cassava landraces is probably an indication of farmers' preferred attributes such as earliness and uses to which the crop is put to. Low occurrence of improved cultivars reported in this study was consistent with earlier findings made in the country by Cudjoe et al., (2005). Dominance of local landraces over improved genotypes have also been reported in other cassava producing areas of Africa (Otim-Nape et al., 1997; Otim-Nape et al., 1998; Otim-Nape et al., 2001; Owor et al., 2004; Mallowa et al., 2006). Majority of the landraces recorded were very much affected by CMD. Further study was necessary to ascertain resistance or susceptibility status of the asymptomatic landraces recorded in the country. 
Cassava mosaic disease was prevalent in the country, occurring in $129(94.8 \%)$ out of the 136 farmers' fields surveyed (Fig. 1). With the exception of Dabor, incidence of CMD in the seven common genotypes (assessed in at least five fields) exceeded 60 per cent (Table 1). Incidence of CMD in these landraces was mainly due to cutting-borne infections. Interestingly, CMD incidence was also pronounced in less common cultivars, reaching 100 percent in most cases (data not shown). Incidence of CMD also varied between districts, from $9 \%$ in the Wenchi district in the Brong Ahafo region to 100 percent in the Bia and Juabeso districts in the Western Region (Table 2). Overall mean plant CMD incidence was 66.0 percent, with Cutting-borne infection being 54.0 percent, which is indicative of the extent to which farmers used infected cuttings in establishing their farms. Mean incidence of the disease ranged from $46.0 \%$ in Ashanti region to 90.0 percent in Western region (Table 3). Field CMD incidence was greater than $80 \%$ in all the regions and reached $100 \%$ in Ashanti and Western regions.

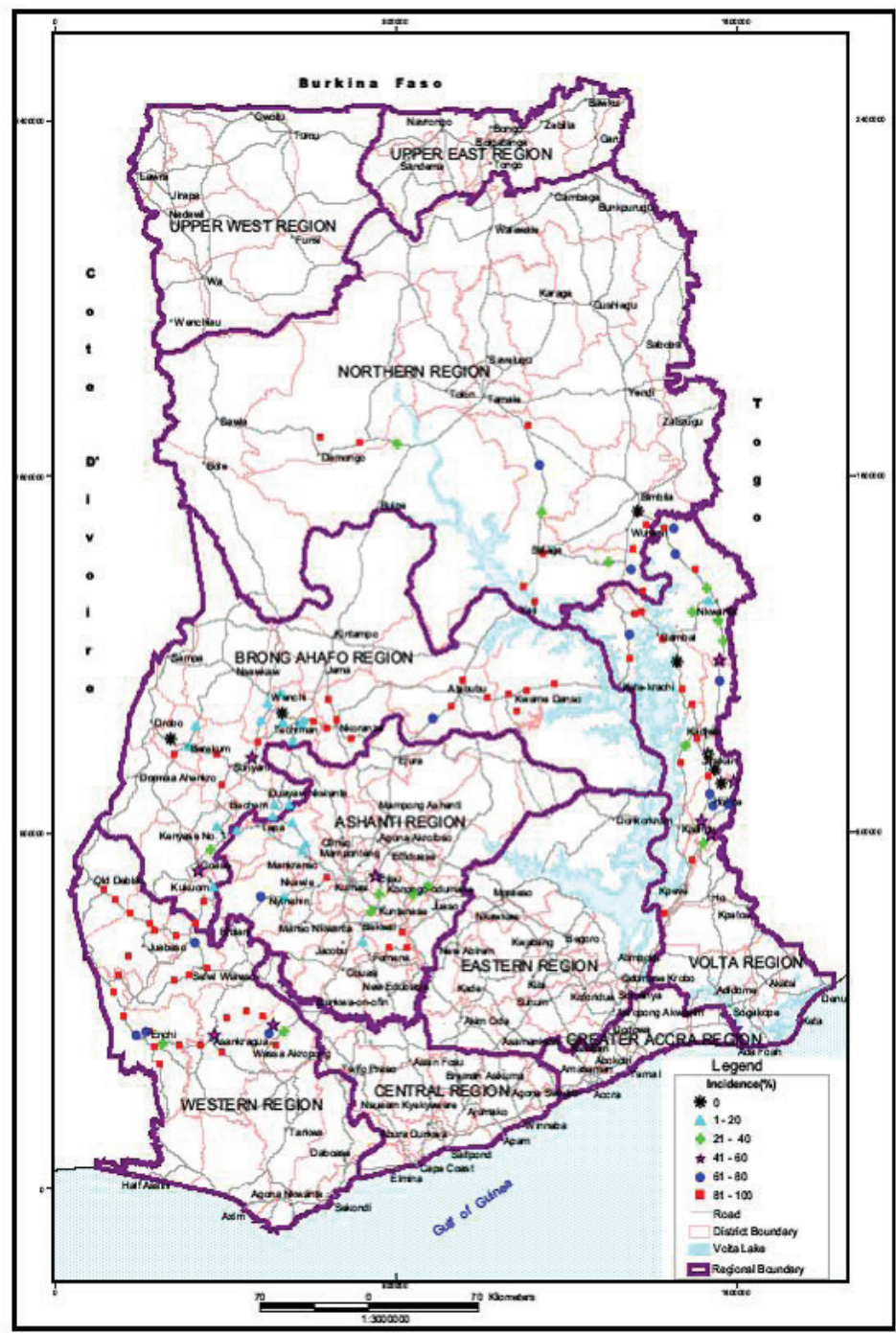

Fig. 1. Distribution of cassava farms in Ghana showing mean CMD incidence levels 
TABLE 2

CMD incidence in farmers' fields in 33 major cassava producing districts

\begin{tabular}{|c|c|c|c|c|c|}
\hline \multirow[t]{2}{*}{ Region } & \multirow[t]{2}{*}{ District } & \multirow{2}{*}{$\begin{array}{l}\text { Number } \\
\text { of farms } \\
\text { visited }\end{array}$} & \multicolumn{3}{|c|}{ CMD infection $(\%)^{I},{ }^{a}$} \\
\hline & & & Incidence & $\begin{array}{l}\text { Cutting- } \\
\text { Borne }\end{array}$ & $\begin{array}{l}\text { Whitefly- } \\
\text { Borne }\end{array}$ \\
\hline \multirow[t]{10}{*}{ Brong Ahafo } & Techiman & 8 & $43.3(17.89)$ & $38.3(20.47)$ & $5.0(4.98)$ \\
\hline & Nkoranza & 5 & $75.3(17.46)$ & $66.7(18.90)$ & $8.6(5.48)$ \\
\hline & Wenhci & 3 & $8.9(3.01)$ & $3.3(8.69)$ & $5.6(2.14)$ \\
\hline & Atebubu & 3 & $97.8(7.07)$ & $88.9(16.64)$ & $8.9(14.67)$ \\
\hline & Sene & 4 & $97.5(6.52)$ & $97.5(6.52)$ & $0(0)$ \\
\hline & Asunafo South & 3 & $57.8(26.45)$ & $50.0(36.74)$ & $7.8(10.93)$ \\
\hline & Asutifi & 3 & $21.1(2.90)$ & $7.8(10.93)$ & $13.3(4.73)$ \\
\hline & Sunyani & 3 & $85.6(19.40)$ & $82.3(22.10)$ & $3.3(8.69)$ \\
\hline & Berekum & 3 & $36.738 .82)$ & $34.4(31.91)$ & $2.3(7.07)$ \\
\hline & Tano South & 3 & $10.0(2.61)$ & $1.1(4.93)$ & $8.9(3.01)$ \\
\hline \multirow[t]{4}{*}{ Northern } & Gonja East & 7 & $82.4(10.69)$ & 71.0 (22.99) & $11.4(6.94)$ \\
\hline & Gonja West & 3 & $77.8(25.81)$ & $60.0(37.76)$ & $17.8(14.99)$ \\
\hline & Nanumba North & 2 & $31.7(37.27)$ & $28.3(34.50)$ & $3.4(10.61)$ \\
\hline & Nanumba South & 4 & $80.0(18.29)$ & $57.5(21.76)$ & $22.5(3.7)$ \\
\hline \multirow[t]{6}{*}{ Western } & Sefwi-Wiaso & 6 & $91.7(6.74)$ & $85.6(7.78)$ & $6.1(6.60)$ \\
\hline & Wassa Amanfi East & 5 & $73.3(20.23)$ & $56.0(17.38)$ & $17.3(9.82)$ \\
\hline & Juabeso & 3 & $100(0)$ & $82.2(6.38)$ & $17.8(6.38)$ \\
\hline & $\mathrm{Bia}$ & 3 & $100(0)$ & $100(0)$ & $0.0(0)$ \\
\hline & Aowin Suaman & 10 & $85.7(9.16)$ & $66.7(12.71)$ & $19.0(8.72)$ \\
\hline & Wassa Amanfi West & 5 & $92.0(11.09)$ & $86.0(14.00)$ & $6.0(8.00)$ \\
\hline \multirow[t]{6}{*}{ Volta } & Nkwanta & 9 & $49.3(12.29)$ & $23.7(11.42)$ & $25.6(4.12)$ \\
\hline & Krachi West & 5 & $95.3(8.16)$ & $80.0(4.15)$ & $15.33 .02)$ \\
\hline & Krachi East & 4 & $75.0(31.82)$ & $62.5(26.91)$ & $12.51(2.53)$ \\
\hline & Hohoe & 9 & $53.0(11.39)$ & $24.8(11.33)$ & $28.2(6.65)$ \\
\hline & Jasikan & 7 & $56.2(21.15)$ & $34.3(16.77)$ & $21.910 .19)$ \\
\hline & South Dayi & 1 & $100(0)$ & $100(0)$ & $0 . \quad(0)$ \\
\hline \multirow[t]{7}{*}{ Ashanti } & Asante Akim North & 2 & $28.0(1.48)$ & $0(0)$ & $28.0(1.48)$ \\
\hline & Amansie East & 4 & $78.0(24.26)$ & $78.0(24.26)$ & $0(0)$ \\
\hline & Ahafo Ano South & 3 & $14.0(3.36)$ & $3.0(10.64)$ & $11.0(1.39)$ \\
\hline & Atwima Nwabiagya & 1 & $100(0)$ & $100(0)$ & $0(0)$ \\
\hline & Ejusu Juaben & 2 & $45.0(4.08)$ & $20.0(3.35)$ & $25.0(7.87)$ \\
\hline & Bosomtwe-Atwima- & 1 & $23.0(0)$ & $0(0)$ & $23.0(0)$ \\
\hline & $\begin{array}{l}\text { Kwahoma } \\
\text { Atwima Mponua }\end{array}$ & 2 & $37.0(24.24)$ & $25.0(31.82)$ & $12.0(2.09)$ \\
\hline Grand mean & & & $66.0(14.13)$ & $54.0(15.80)$ & $12.0(5.93)$ \\
\hline
\end{tabular}

${ }^{1}$ Thirty plants were randomly sampled per field; ${ }^{a}$ Figures in parentheses are standard error of difference values 
TABLE 3

CMD Severity and adult whitefly counts in farmers'fields in 33 major cassava producing districts

\begin{tabular}{|c|c|c|c|c|}
\hline Region & District & $\begin{array}{l}\text { Number } \\
\text { of farms } \\
\text { visited }\end{array}$ & $\begin{array}{l}\text { Severity } \\
(1-5)^{2, a}\end{array}$ & $\begin{array}{l}\text { Adult } \\
\text { Whitefly } \\
\text { Counts } 3, a\end{array}$ \\
\hline \multirow[t]{10}{*}{ Brong Ahafo } & Techiman & 8 & $2.7(0.31)$ & $0.23(0.05)$ \\
\hline & Nkoranza & 5 & $3.0(0.21)$ & $0.29(0.23)$ \\
\hline & Wenhci & 3 & $2.7(0.47)$ & $0.33(0.07)$ \\
\hline & Atebubu & 3 & $3.0(0.29)$ & $0.23(0.04)$ \\
\hline & Sene & 4 & $2.9(0.12)$ & $0.24(0.02)$ \\
\hline & Asunafo South & 3 & $2.9(0.64)$ & $0.52(0.05)$ \\
\hline & Asutifi & 3 & $3.0(0)$ & $0.24(.01)$ \\
\hline & Sunyani & 3 & $3.4(0.21)$ & $0.42(0.04)$ \\
\hline & Berekum & 3 & $3.3(0.42)$ & $0.34(0.07)$ \\
\hline & Tano South & 3 & $2.4(0.42)$ & $0.19(0.09)$ \\
\hline \multirow[t]{4}{*}{ Northern } & Gonja East & 7 & $2.8(0.22)$ & $0.14(0.05)$ \\
\hline & Gonja West & 3 & $2.6(0.42)$ & $0.13(0.06)$ \\
\hline & Nanumba North & 2 & $2.6(0)$ & $0(0)$ \\
\hline & Nanumba South & 4 & $2.7(0.35)$ & $0.40(0.15)$ \\
\hline \multirow[t]{6}{*}{ Western } & Sefwi-Wiaso & 6 & $3.2(0.34)$ & $0.94(0.09)$ \\
\hline & Wassa Amanfi East & 5 & $2.8(0.35)$ & $0.71(0.07)$ \\
\hline & Juabeso & 3 & $3.1(0.34)$ & $0.47(0.08)$ \\
\hline & & 3 & $3.5(0.05)$ & $1.05(0.16)$ \\
\hline & Aowin Suaman & 10 & $2.9(0.23)$ & $0.95(0.12)$ \\
\hline & Wassa Amanfi West & 5 & $3.4(0.15)$ & $0.84(0.09)$ \\
\hline \multirow[t]{6}{*}{ Volta } & Nkwanta & 9 & $2.6(0.21)$ & $0.51(0.08)$ \\
\hline & Krachi West & 5 & $2.8(0.10)$ & $0.36(0.13)$ \\
\hline & Krachi East & 4 & $2.8(0.16)$ & $0.50(0.15)$ \\
\hline & Hohoe & 9 & $2.5(0.25)$ & $0.65(0.07)$ \\
\hline & Jasikan & 7 & $2.7(0.34)$ & $0.71(0.08)$ \\
\hline & South Dayi & 1 & $3.0(0)$ & $0.37(0)$ \\
\hline \multirow[t]{7}{*}{ Ashanti } & Asante Akim North & 2 & $2.6(0)$ & $0.48(0.11)$ \\
\hline & Amansie East & 4 & $3.2(0.11)$ & $0.4(0.03)$ \\
\hline & Ahafo Ano South & 3 & $3.0(0)$ & $0.47(0.13)$ \\
\hline & Atwima Nwabiagya & 1 & $3.1(0)$ & $0.67(0)$ \\
\hline & Ejusu Juaben & 2 & $3.0(0)$ & $0.45(0.04)$ \\
\hline & Bosomtwe-Atwima-K. & 1 & $3.0(0)$ & $0.87(0)$ \\
\hline & Atwima Mponua & 2 & $2.6(0.85)$ & $0.42(0.01)$ \\
\hline Mean & & & $2.9(0.17)$ & $0.47(0.05)$ \\
\hline
\end{tabular}

${ }^{2}$ Mean shoot severity on a scale of 1-5 (of increasing severity); ${ }^{3}$ Mean adult whitefly numbers; ${ }^{\text {a }}$ Figures in parentheses are standard error of difference values

High CMD incidence recorded in the present study was consistent with other findings in the country (Cudjoe et al., 2005; Wydra \& Verdier, 2002) and other parts of Africa (Fauquet \& Fargette, 1990; Legg \& Ogwal, 1998; Otim-Nape et al., 1998; Legg, 1999; Otim-Nape et al., 2001; Echendu et al., 2005; Ntawuruhunga et al., 2007). Much of the CMD incidence was cutting-derived infections and concurs with reports in Benin (Gbagyidi et al., 2005), Congo (Ntawuruhunga et al., 2007) and Kenya (Were et al., 2003, 2004; Mallowa et al., 2006). High incidence of cutting-derived infections posed a serious CMD management problem in the country because there was a high likelihood of unlimited 
sources of inoculum in the fields. High incidence of cutting-borne infection coupled with the continuous use of diseased planting materials would result in increased incidence and severity, and could lead to reduction in cassava yield (Muimba-Kankolongo \& Phuti, 1987).

Majority of the fields expressed moderately severe symptoms (Fig. 2). The highest mean CMD severity of 3.7 was recorded in Antwikrom in the Brong Ahafo region. There were differences in the severity levels both within and between districts. CMD severity ranged from 2.4 in Tano South to 3.5 in the $\mathrm{Bia}$ district (Table 3). Overall mean severity was 2.9.

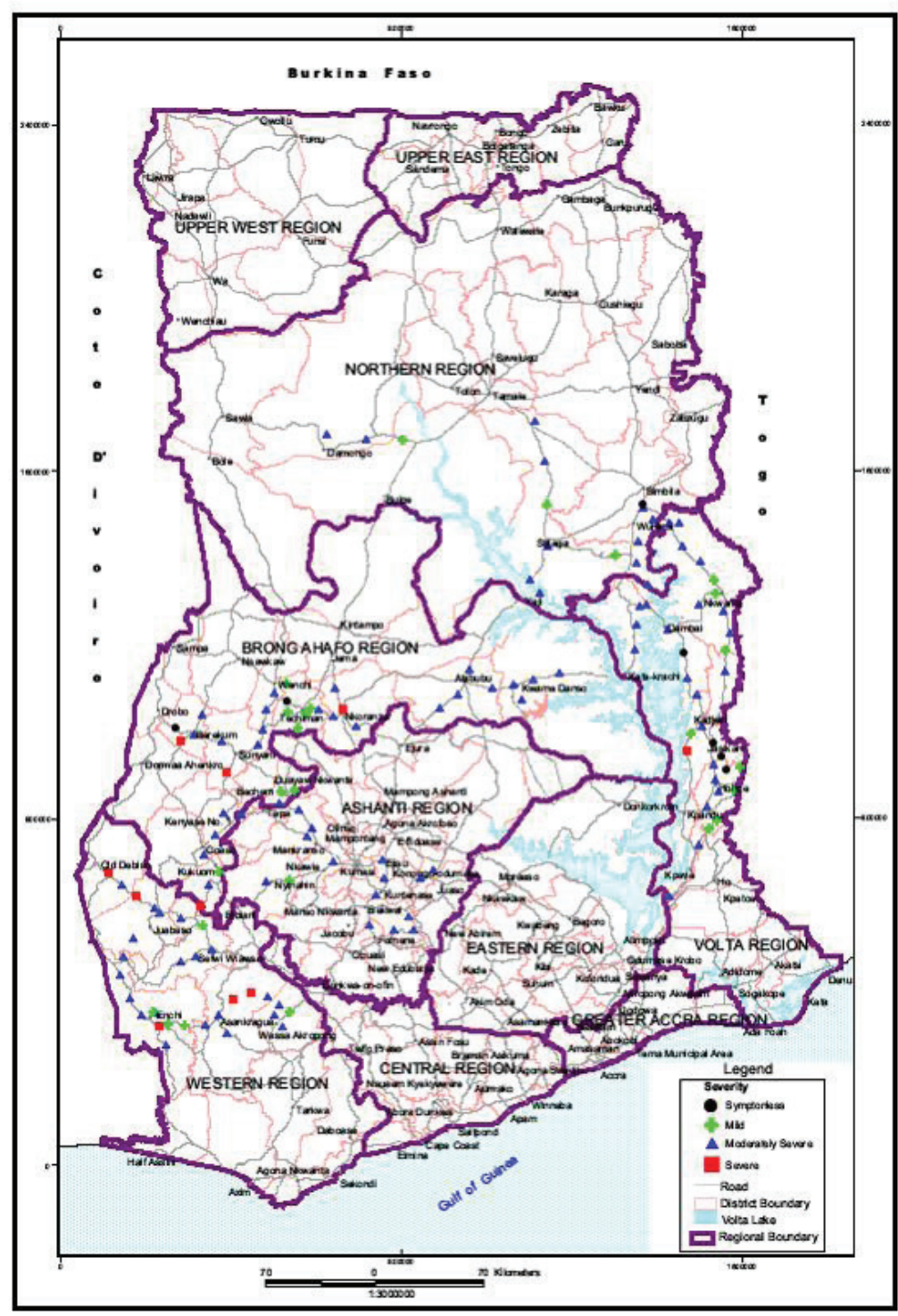

Fig. 2. Distribution of cassava farms in Ghana showing mean CMD severity levels
Mean severity ranged from 2.7 in the Northern and Volta to 3.2 in the Western region (Table 4). Severity for the seven common local cassava genotypes (assessed in at least five fields) ranged from 2.6 to 3.2 with overall mean of 2.9 (Table 5). Mean CMD severity was greater than three in most uncommon cultivars. 
Occurrence of many diseased plants in fields will limit the number of asymptomatic plants to be selected as planting materials. Similarly, severely diseased plants cannot be used as planting materials (cuttings) or produce seeds, which may be used in raising planting materials. In addition, Otim-Nape et al., (1994) have reported positive correlation between symptom severity and reduction in storage root. High CMD severity was observed on well weeded fields contradicting the finding of Banito et al., (2007). Maintaining a weedfree cassava field could therefore be helpful when uninfected cassava cuttings are used in establishing farms.

TABLE 4

Field, plant incidence (\%) and frequency distribution (\%) in four cassava mosaic disease severity classes in five major cassava producing regions in Ghana

\begin{tabular}{|c|c|c|c|c|c|c|c|}
\hline \multirow[t]{2}{*}{ Region } & \multirow{2}{*}{$\begin{array}{l}\text { No. of } \\
\text { Fields } \\
\text { visited }\end{array}$} & \multirow{2}{*}{$\begin{array}{l}\text { Field } \\
\text { Incidence }^{y} \\
(\%)\end{array}$} & \multirow{2}{*}{$\begin{array}{l}\text { Plant } \\
\text { Incidence }^{a, z} \\
(\%)\end{array}$} & \multicolumn{4}{|c|}{ Plants in severity classes ${ }^{x}(\%)$} \\
\hline & & & & 2 & 3 & 4 & 5 \\
\hline Brong Ahafo & 38 & 94.7 & $53.0(1.59)$ & 15.3 & 21.7 & 14.2 & 1.8 \\
\hline Northern & 16 & 93.8 & $68.0(2.65)$ & 29.0 & 27.0 & 12.0 & 0.0 \\
\hline Volta & 35 & 88.6 & $71.0(1.87)$ & 29.5 & 28.3 & 12.4 & 1.1 \\
\hline Ashanti & 15 & 100 & $46.0(2.45)$ & 10.8 & 21.3 & 13.8 & 0.0 \\
\hline Western & 32 & 100 & $90.0(2.17)$ & 21.6 & 31.4 & 25.5 & 11.8 \\
\hline
\end{tabular}

Severity classes: class 2: mild chlorotic patterns and slight distortion of only the base of leaves; class 3: mosaic patterns on all leaves, leaf distortion; class 4: mosaic patterns on all leaves, leaf distortion, and general reduction in leaf size; class 5: leaves twisted/misshapen and stunting; ${ }^{x}$ Percentage of infected plants from all plants sampled in the region;

${ }^{y}$ Percentage of infected fields in the region; ${ }^{z}$ percentage of whole plants diseased.

TABLE 5

Mean CMD severity and adult whitefly counts in five major cassava producing regions in Ghana

\begin{tabular}{llll}
\hline Region & Number & CMD & Whitefly \\
& of sites & Severity & counts $^{a, 3}$ \\
& Visited & ${ }_{\text {a, }}$ &
\end{tabular}

\begin{tabular}{llll}
\hline Brong Ahafo & 38 & $2.9(0.4)$ & $0.30(0.31)$ \\
\hline Northern & 16 & $2.7(0.6)$ & $0.17(0.47)$ \\
\hline Volta & 35 & $2.7(0.4)$ & $0.52(0.32)$ \\
\hline Western & 32 & $3.2(0.4)$ & $0.83(0.35)$ \\
\hline Ashanti & 15 & $2.9(0.6)$ & $0.54(0.49)$ \\
\hline Mean & & $2.9(0.29)$ & $0.47(0.11)$ \\
\hline
\end{tabular}

${ }^{a}$ Figures in parentheses are standard error of difference values; ${ }^{2}$ Mean shoot severity on a $1-5$ scale of increasing severity; ${ }^{3}$ Mean adult whitefly numbers

Adult whitefly populations were generally low. The highest mean adult whitefly population of 1.05 was recorded in Bia district in the Western region whereas no adult whiteflies were recorded in the Nanumba North district (Table 2). Overall mean adult whitefly population was 0.47 (Table 4). The low numbers notwithstanding, there were differences between districts and to a lesser extent between regions. Low whitefly populations reported in 
the present study was consistent with the findings of Cudjoe et al., (2005), in which the mean adult whitefly populations ranged between 0.3 and 1.3 for most regions in the country. Low adult whitefly populations have also been reported in some districts of Uganda (Otim-Nape et al., 1998). However, findings of this study contradict the generally high adult whitefly populations reported in the Central transect of Uganda (Legg \& Ogwal, 1998) and Uganda (Otim-Nape et al., 2001). In areas of no or low adult whitefly population, phytosanitation methods, such as selection of CMD-free materials and rouging could be adopted as CMD management practice. Such areas would also be ideal for multiplication of planting materials.

Out of the 136 farmers' cassava fields surveyed, 25\% were pure stands. Mean CMD incidence and severity of these fields were $73 \%$ and 2.9 respectively. Mean adult whitefly population was also 0.39. Cassava mixtures (fields established with more than one cassava genotype) appeared to have favoured high CMD incidence (81\%) as opposed to sole genotype $(66 \%)$ in the monocropped fields. CMD shoot severity was almost the same, being 2.9 and 2.8 for cassava fields with mixtures and sole genotype farms, respectively. Mean CMD incidence, severity and adult whitefly numbers for intercropped cassava farms were 69\%, 2.9 and 0.59 respectively, which were similar to those found on monocropped fields.

Cassava mixtures supported a high CMD incidence and adult whitefly numbers of $72 \%$ and 0.67 , respectively in intercropped fields. Mean CMD incidence and adult whitefly population in fields without mixtures were $61 \%$ and 0.44 , respectively. The type of food or cash crops, in the farmers' localities influenced the choice of intercrop to a very large extent.Cassa- va mixtures had been explored for CMD management (Sserubombwe et al., 2001). In this study, majority of the cassava in the mixtures were diseased, and would serve as sources of inoculum, contradicting the findings of Osiru et al., (1999), who reported that varietal mixtures consistently and significantly decreased the incidence of CMD compared to their corresponding pure stand treatments. Also, the apparent lack of effect of mixtures on CMD severity did not concur with findings in Togo (Banito et al., 2007), where CMD severity increased when several cassava varieties were grown in a mixture in a field. Sserubombwe et al., (2001) reported that the benefit of mixtures could be realized when resistant genotypes were incorporated in mixtures. Therefore, superiority of resistance of the plants in the mixtures would be important in controlling CMD, and this should be encouraged in the country.

Lack of apparent effect of intercrops on CMD incidence and adult whitefly population reported in this study contradicted the findings of Fondong et al. (2002) and consistent with the observation of Fondong et al., (2002). Intercropping of cassava with other crops had no significant effect on severity of CMD infection because most of the infections had arisen from cutting-borne planting material.

\section{Conclusion}

Cassava mosaic disease was found to be prevalent in this study, reaching 100 percent in some districts. Plants showing very severe mosaic symptoms were seen on many farmers' fields, hence the fear of high sustained yield losses. These call for regular CMD monitoring surveys and determination of viruses associated with the disease to ensure successful management of the disease. 


\section{Acknowledgement}

The authors wish to thank the Agriculture Services sub-Sector Investment Programme (AgSSIP), United States Agency for International Development (USAID) and University of Ghana for funding the Research. We are also thankful to the Directors of Agriculture and staff in the survey areas for their co-operation.

\section{REFERENCES}

Banito, A., Verdier, V., Kpémoua, K. E. \& Wydra, K. (2007) Assessment of major cassava diseases in Togo in relation to agronomic and environmental characteristics in a systems approach. African J. Agric. Res 2 (9), 418 - 428.

Bokanga, M. \& Otoo, E. (1994) Cassava based foods: how safe are they. In: Tropical root crops in a developing economy. Ofori, F. \& Hahn, S. K. (eds.). Proceedings of the $9^{\text {th }}$ Symposium of the International Society for Tropical Root Crops, 20-26 October 1991, Accra, Ghana. pp. 225 234.

Cudjoe, A., Gyamenah, J. \& Braima, J. (2005) Chapter 1.2 (Ghana) In: Whiteflies and whitefly-borne viruses in the tropics: Building a knowledge base for gglobal action. P.K. Anderson, F.J. Morales, A.L. Jones and R.H. Markham (eds). Arte Libro Impresores, Cali. Colombia. pp. $24-25$.

Echendu, N. C., Ojo, J. B., James, B. \& Gbaguidi, B. (2005) Chapter 1.4 (Nigeria) In: Whiteflies and whitefly-borne viruses in the tropics: Building a knowledge base for global action. P.K. Anderson, F.J. Morales, A.L. Jones and R.H. Markham (eds). Arte Libro Impresores, Cali. Colombia. pp. $35-39$.

FAO (2006). FAO year book on Ghana.

Fauquet, C. \& Fargatte, D. (1990) African cassava mosaic virus: etiology, epidemiology and control. Plant Dis 74, $404-411$.
Fondong, V. N., Thresh, J. M. \& Zok, S. (2002) Spatial and temporal spread of cassava mosaic virus disease in cassava grown alone and when intercropped with maize and/or cowpea. $J$. Phytopathol 150 (7), 365 - 374

Gbaguidi, B., James, B. \& Saizonou, S. (2005) Chapter 1.3 (Benin) In: Whiteflies and whitefly-borne viruses in the tropics: Building a knowledge base for global action. P.K. Anderson, F.J. Morales, A.L. Jones and R.H. Markham (eds), pp. 30-34. Arte Libro Impresores, Cali. Colombia.

Hahn, S. K., Terry, E. R. \& Leuschner, K. (1980) Breeding cassava for resistance to cassava mosaic disease. Euphyt 29, 673-683.

Lamptey, J. N. L., Okoli, O. O. \& Frimpong-Manso, P. P. (1998) Incidence and severity of African cassava mosaic disease (ACMD) and cassava bacterial blight (CBB) on some local and exotic cassava varieties in different ecological zones in Ghana. Ghana J. Agric. Sci. 31, 35-43.

Legg, J. P. (1999) Emergence, spread and strategies for controlling the pandemic of cassava mosaic virus disease in East and Central Africa. Crop Protect. 18, 627-637.

Legg, J. P. \& Ogwal, S. (1998) Changes in the incidence of African cassava mosaic virus disease and the abundance of whitefly vector along south-north transects in Uganda. J. App. Entomol 122, $169-178$.

Legg, J. P. \& Fauquet, C. M. (2004) Cassava mosaic geminiviruses in Africa. Plant Mol. Biol 56, $585-599$.

Mallowa, S. O., Isutsa, D. K. , Kamau, A. W. , Obonyo, R. \& Legg, J. P. (2006) Current characteristics of cassava mosaic disease in postepidemic areas increase the range of possible management options. Annals of Applied Biology 149, 137-144.

MOFA (2007) Statistics research and information directorate, Annual sample survey of agriculture in Ghana, Accra. 
MOFA (2016) Statistics research and information directorate, Annual sample survey of agriculture in Ghana, Accra.

Muimba-Kankolongo, A. \& Phuti, K. (1987) Relationship of cassava mosaic severity in planting material to mosaic development, growth and yield of cassava in zaire. Exptl. Agric 23, 221 -225 .

Ntawuruhunga, P., Okao-Okuja, G., Bembe, A., Obambi, M., Armand Mvila, J. C. \& Legg, J. P. (2007) Incidence and severity of cassava mosaic disease in the Republic of Congo. African Crop Sci. J 15 (1), 1 - 9.

Osiru, D. S. O., Sserubombwe, W. S., Sseruwagi, P., Thresh, M. \& Otim-Nape, G. W. (1999) Effects of cassava mosaic virus disease on the growth and yield of cassava - some highlights from Makerere experiments. African Crop Sci. J 7 (4), $511-522$.

Otim-Nape, G. W., Shaw, M. W. \& Thresh, J. M. (1994) The effects of African cassava mosaic geminivirus on the growth and yield of cassava in Uganda. Trop. Sci 34, 43-54.

Otim-Nape, G. W., Bua, A., Thresh, J. M., Baguma, Y., Ogwal, S., Ssemakula, G. N., Acola, G., Byabakama, B. A., Colvin, J., Cooter, R. J. \& Martin, A. (1997) Cassava mosaic virus disease in East Africa and its control. Natural Resources Institute, Chatham, UK. pp. 100.

Otim-Nape, G. W., Thresh, J. M. \& Shaw, M. W. (1998) The incidence and severity of cassava mosaic virus disease in Uganda: 1990-92. Trop. Sci 38, $25-37$.

Otim-Nape, G. W., Alicai, T. \& Thresh, J. M. (2001) Changes in the incidence and severity of cassava mosaic virus disease, varietal diversity and cassava production in Uganda. Ann. Appl. Biol 138, $313-327$.

Owor, B., Legg, J. P., Okao-Okuja, G., Obonyo, R., Kyamanywa, S. \& Ogenga- Latigo, M.W.
(2004) Field studies of cross protection with cassava mosaic geminiviruses in Uganda. $J$. Phytopathol 152 (4), 243 - 249.

Sserubombwe, W. S., Thresh, J. M., Otim-Nape, G. W. \& Osiru, D. O. S. (2001) Progress of cassava mosaic virus disease and whitefly vector populations in single and mixed stands of four cassava varieties grown under epidemic conditions in Uganda. Ann. Appl. Biol 138, 161-170.

Sseruwagi, P., Sserubombwe, W.S., Legg, J.P., Ndunguru, J. \& Thresh, J.M. (2004) Methods of surveying the incidence and severity of cassava mosaic disease and whitefly vector populations in Africa: a review. Virus Res 100, 129 - 142.

Thresh, J. M., Fargette, D. \& Otim-Nape, G. W. (1994) Effects of African cassava mosaic geminivirus on the yield of cassava. Trop. Sc 34, $26-42$.

Torkpo, S. K. \& Offei, S. K. (2007) Status of cassava mosaic disease in farmers' fields. Book of Abstracts of the 25th biennial Conference of the Ghana Science Association held at Bunso and Tafo in the Eastern Region between August 5-10, 2007.

Were, H. K., Winter, S. \& Maiss, E. (2003) Distribution of begomoviruses infecting cassava in Africa. J. Plant Pathol 85 (3), 145 - 151.

Were, H.K., Winter, S \& Maiss, E. (2004) Occurrence and distribution of cassava begomovirses in Kenya. Ann. Appl. Biol 145 (2), 175 - 184.

Wydra, K. \& Verdier, V. (2002) Occurrence of cassava diseases in relation to environmental, agronomic and plant characteristics. Agric. Ecosystems \& Environment 93 (1-3), 211 - 226. 